\title{
Library and Information Retrieval Instruction: Competency Testing
}

At Findlay College competency requirements in reading, writing, mathematics, and the library have been integrated into the general curriculum since the mid-1970s. They developed out of a strong concern among the faculty and the administration that the college needed to respond to wide varieties of student achievement as well as identify minimum academic skill levels. ${ }^{1}$ Seven years later the college continues to maintain the original competency requirements, and during the past year serious consideration has been given to including competencies in speech and computer literacy. The competency requirements are included beyond the 128 degree credit hours. The library and information retrieval competency, like the other competency skills, is a graduation requirement and must be completed by both full and part-time students for junior standing at the college.

The term "competency-based instruction" may raise several possible definitions, but generally within the scope of college and university instruction the term "competency" has stood as a specific measure of skill and knowledge. The use of competency-based instruction revolves around the use of specific or accepted levels of skill and knowledge attainment which are demonstrable and measurable, and which an institution can certify and/or classify. A majority of the institutions in higher education which use competency-based instruction have preconceived minimum levels of acceptance which individuals (students) must meet to fulfill specific competencies. ${ }^{2}$

The use of competency-based instruction in higher education has been the result of two contemporary trends. One, there has been a movement in certain colleges and universities during the past decade to turn the curriculum back to

\footnotetext{
${ }^{1}$ Findlay College Competency Handbook, 1975.

${ }^{2}$ Gerald Grant, et al., On Competence: A Critical Analysis of Competence-Based Reforms in Higher Education (San Francisco: Jossey-Bass, 1979), pp. 18-65; David A. Trivett, Competency Programs in Higher Education, ERIC/Higher Education Research Report No. 7 (Washington: American Association for Higher Education, 1975); and Vince T. Peterson, ed., Renewing Higher Education: The Competency-Based Approach (Toledo: Center for the Study of Higher Education, University of Toledo, 1976).
}

the "basics." And two, there has been a movement in some institutions to provide certification that students have acquired and can perform certain academic skills.

The acceptance of a competency-based form of instruction in colleges or universities has been scattered across the country among various institutional types. For example, the following colleges and universities have designed significant segments of their curriculum around a competency format: Alverno College in Wisconsin, the College of Human Services in New York City, Mt. Hood Community College in Oregon, Florida State University, and College IV associated with Grand Valley State College in Michigan. ${ }^{3}$ Competency-based instruction in higher education has received a certain amount of public support as people have clamored about declining test scores as well as the skill and literacy levels of college and university graduates. However, the institutional accomodation of the competency approach to curriculum development and institutional process is still dependent upon the willingness of the faculty to design and implement this format.

There is relatively little in the literature which substantiates the use of competencies in the implementation of bibliographic instruction. ${ }^{4}$ The use and acceptance of a library and information retrieval competency at Findlay College is partly due to acceptance and use of competencies in other curricular forms at the college. Competencies at Findlay College are used to certify that students have acquired and can demonstrate certain minimum levels of skill and knowledge proficiency.

Briefly, Findlay College is a small private college with relatively non-selective admission

${ }^{3}$ Grant, On Competence.

${ }^{4}$ Carla J. Stoffle \& Judith M. Pryor, "Competency-Based Education and Library Instruction," Library Trends 29 (Summer 1980):58-65. The authors list the following institutions which use competencies in library instruction: Alverno College, Doane College, Sangamon State University, University of Louisville, Findlay College, and the University of WisconsinParkside. See also Richard Hume Werking, "Evaluating Bibliographic Education: A Review and Critique," Library Trends 29 (Summer 1980):153-72. 


\section{Coming Attraction!}

22 Years of Organic Chemistry (1960-1981)

\section{Current Abstracts of}

\section{Chemistry and Index} Chemicus $^{\circ}$

\section{on convenient microfilm or microfiche}

\section{Special Pre-Publication Offer}

CAC\&/C ${ }^{\circ}$ from 1960 through 1981 will be available in microform in 1983. For the first time, you'll have convenient access to the new organic compounds reported in over two decades of the chemical journal literature. And if you act before November 1,1982 , you'll receive a $20 \%$ price reduction on CAC\&IC 1960-1981:

\section{industrial subscription \\ after publication $\$ 10,000 \ldots$ NOW $\$ 8,000$}

\section{for educational institutions}

after publication $\$ 5,000 \ldots$ NOW $\$ 4,000$

\section{You'll Have Access to Over 3 Million Unique Organic Compounds}

$C A C \& I C$ indexes new organic compounds as they appeared in the literature over the past 22 years. The highly visual, graphic format of $C A C \& / C$ facilitates rapid scanning - each abstract is designed to give you the maximum amount of information with the minimum investment of your time. All abstracts provide complete bibliographic information for the journal article in which the compound was first reported, plus:

- specific applications for which the compound was tested

- techniques used in analyzing the compound

- author's abstract from the original article

- easy-to-scan structural diagrams for each compound: Anticancer activitr

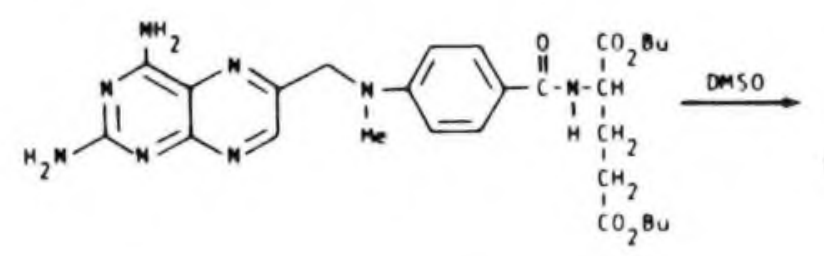

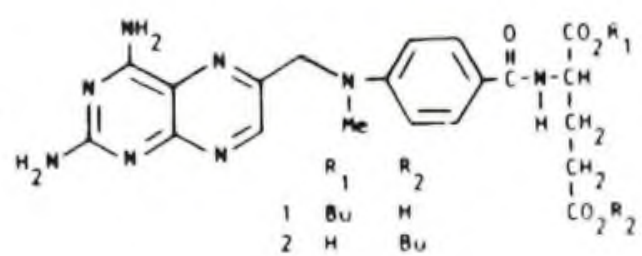

Eight indexes, including subject, author, and corporate, make specific searching quick and efficient.

Annual updates will be available each year beginning with 1982 .

To place your order, write to:

号员" Institute for $\smile$ Scientific Information"

Chemical Information Division, Marketing Department 3501 Market Street

Philadelphia, PA 19104

Telephone: toll-free: 800-523-1850, extension 1432 Residents of Pennsylvania, call collect: 215-386-0100, extension 1432 Telephone orders must include P.O. number.

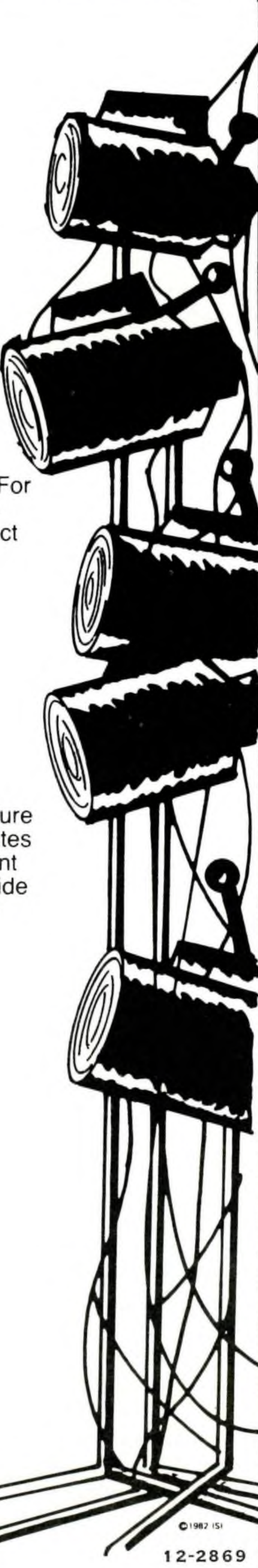


standards and a curriculum which consists of a blending of the liberal arts and career preparation. The college has maintained a flexible approach to curriculum building and instructional methods, and through careful planning and marketing it has experienced enrollment growth over the past three years. In addition to the resident undergraduate population, Findlay College has strong continuing education and weekend college programs. Currently the enrollment is 1,300 (975 FTE) with 55 full-time faculty and a library staff of 3.5 professionals and 3.5 non-professionals.

The library and information retrieval competency at Findlay College was initially conceived to function at a Level I (basic) and a Level II (advanced), but the complexity of administering the competency requirement with a small library staff prevented the staff from developing a Level II. At the same time competency-based instruction was incorporated into the Findlay College curriculum, another new curricular design was established-the freshman seminar. These seminars were designed for all freshman students and were team taught by faculty identified as strong classroom teachers. The purpose of the freshman seminars was to combine academic content and socialization for newly enrolled students, and the seminars presented ideal formats to initiate the competencies.

During the first three years of the competency program, the library and information retrieval competency received modest support in the seminars. In 1978, however, the faculty voted to make the library competency a requirement to be completed by the second semester of the sophomore year. Since 1978, through promotion and individual planning with the freshman seminar faculty, a greater acceptance of the library competency has occurred. During the past two years the public services librarian has worked closely with all freshman seminar faculty to integrate library instruction relating to the library competency into the theme of each seminar. He has also received the cooperation of freshman seminar faculty in the testing and administration of the competency examination; this same pattern of cooperation has spread to other areas of the college, such as the division of continuing education and the weekend college.

At Findlay's Shafer Library the competency is conceived as a basic approach to teaching specific library and information skills and knowledge. The program consists of three parts: orientation, instruction, and examination. The orientation and instruction segment requires the librarian to spend approximately two hours in the classroom. Instruction on the library is integrated into the major theme or content of the specific course or seminar. The content of the instruction is twofold. Part one is informational (skills), showing students where resources and services are located in Shafer Library; and part two is knowledge, showing students how to use basic reference and retrieval sources. The methods of instruction have varied and have included the use of handouts, multimedia presentations, and tours of the library and media center. The instructional sequence usually takes place between the fourth and the twelfth week of the 18-week fall semester.

The philosophy behind the library competency at Findlay College is not to assume that the student has an understanding of the library. The competency process is therefore intended to provide the student with an understanding of library media services and resources which can be measured at a basic minimum level. Library instruction is designed to acquaint the learner with both the knowledge of library and media resources and the skill to retrieve basic information and data to use in fulfilling class and seminar requirements. Students are introduced to the card catalog and the Library of Congress classification system as well as the various indexes and abstracts maintained by the library. Differences and similarities among various resources are explained to the student. A simple and graphic approach is made in explaining citations as well as the physical location of specific sources. The use of slides to highlight the library/media facility coupled with a tour of the facility provides the student with a familiarity with the library and the personnel. One of the outcomes of this approach for Shafer Library is that students (particularly freshman and part-time students) develop an awareness and a confidence in an academic library.

After completing the instructional unit, the librarian returns to the individual class or seminar two to three weeks later to administer the competency exam, which requires that the student recall informational as well as instructional components of the library. Students need to know the physical facility as well as where resources and services are located, and they must be able to correctly read citations as well as interpret basic reference and retrieval sources (card catalog and indexes). The written portion of the examination is composed of 33 questions. A student who fails more than six questions must retake the examination and/or confer individually with a librarian. In addition, each student is expected to successfully retrieve an item from the collection as well as locate a citation in the New York Times Index and find the source on microfilm.

The success of any good library instruction program, especially a competency-based model, is based on both quantitative and qualitative measures of evaluation. During the initial years of the library competency, little constructive or systematic evaluation was made of the program. Since 1980 this has changed substantially. For example, of the freshman seminar students who took the competency in $1980,41 \%$ were successful on the first examination, while in 1981 this figure im- 
proved to $57 \%$. In fall term 1981, 281 freshman students out of 325 took the competency instruction and examination; this represents seven seminars and fifteen teaching faculty. It ought to be noted that one group of students - those majoring in equestrian studies-are exempted from the freshman seminar sequence; however, they are required to take and pass the library and information retrieval examination for graduation. These students receive library instruction through their equestrian classes.

The evaluation of the library competency as a form of library instruction at Findlay College illustrates that progress has been made, particularly in the area of faculty acceptance and the numbers of students involved in the process. The percentage of students successful with the competency substantiates to some degree the wide variety of achievement levels represented by the Findlay College student body. It also identifies for the library and media staff the constant need to examine the content of the competency process as well as the methods of instruction and testing. Perhaps most significant for the library at Findlay College is the fact that the library competency is considered an integral part of the college's curriculum and a requirement for graduation. Part of our mission is to serve as an opendoor institution, and through competency testing

\section{BI WORKSHOPS}

Instruction librarians-if you could not come to the ALA preconferences, they can now come to you.

The Bibliographic Instruction Section, through its Continuing Education Committee, has been awarded a J. Morris Jones World Book Encyclopedia ALA Goal Award of $\$ 5,000$ for its project, "Bringing Worskhops to the Members." This award will provide funds to any state or regional library association to help underwrite the cost of workshops to be offered throughout the country during the 1983 calendar year.

Through this grant workshop leaders from the 1979 and 1981 ACRL/BIS preconferences will re-create their workshops on such topics as: classroom dynamics; conceptual frameworks; course-integrated library instruction; evaluation tools and tactics; library instruction for faculty and graduate students; the one-hour stand; teaching librarians to teach; teaching students to think; and the organization and development of workbooks.

Eligibility: Any state or regional library association, including organizations such as ACRL chapters.

Deadline: Applications are due October 15, 1982. Award announcements will be made in San Antonio at the 1983 Midwinter Conference. in library instruction we feel that Shafer Library plays a visible and direct role in academic planning at the college.

The authors are now compiling longitudinal data which will enable the library and college to evaluate the effectiveness and impact of this form of library instruction on student body habits and use of the college library. Also the authors feel that this type of instruction is applicable to other types of academic library, particularly those which are constrained financially in staff or resources but which need some form of educational process to certify students and users with minimum library and information retrieval skills.

The library and information retrieval competency program performs a real service for all concerned. Students are made aware of much that Shafer Library has to offer and they may benefit from that knowledge throughout their lives. The college obtains a quantifiable measure of achievement and skill. And Shafer Library receives valuable exposure to the students at one of the most impressionable points in their academic career.-Robert Schirmer and G. Charles Newman.

Editor's Note: Robert Schirmer is public services librarian and G. Charles Newman is director of Shafer Library, Findlay College, Ohio.

Applications and Information: Write to Anne Beaubien, Chair, ACRL/BIS Continuing Education Committee, Michigan Information Transfer Source, University of Michigan, 413 Harlan Hatcher Graduate Library, Ann Arbor, MI 48109; (313) 763-5060.

\section{SHINN GETS SNAGGED}

James Richard Shinn pled guilty in July to two counts of unlawful possession and transportation of stolen property before Daniel Huyett III, a judge in the Federal District Court for Eastern Pennsylvania. Shinn's defense lawyer had initially attempted to have the evidence, 16 footlockers of books taken illegally from university libraries across the country, declared "tainted" and therefore suppressed because of Shinn's irregular arrest at Oberlin College by librarian William Moffett. However, the judge ruled that the argument lacked credibility.

Each count carries a maximum of 10 years imprisonment and a fine of $\$ 10,000$. Shinn's sentencing is on August 30, after which he may be liable to extradition from four state jurisdictions. 